\title{
Benign Glottis Neoplasm
}

National Cancer Institute

\section{Source}

National Cancer Institute. Benign Glottis Neoplasm. NCI Thesaurus. Code C4605.

A non-metastasizing neoplasm that arises from the glottis. 